\title{
The Difference in Enamel Surface Hardness after Immersion Process with Cocoa Rind Extract (Theobroma cacao) and Fluoride
}

\author{
Nirawati Pribadi, Anggun Citra, Mandojo Rukmo \\ Department of Conservative Dentistry, Faculty of Dental Medicine, Universitas Airlangga, Surabaya, Indonesia
}

\section{Abstract}

\begin{abstract}
Aims: Enamel is the hardest tissue in the human body and possessing mechanical properties, such as physiological functions as chewing, while protecting the underlying structure. Fluoride increase and improve one of the mechanical properties which is tooth surface hardness, but the excessive use of fluoride has the risk of fluorosis. Theobromine in cacao rind extract could potentially be used as an alternative herbal ingredient. Theobromine increases tooth enamel surface hardness through interstitial reactions. The aim of this study is to analyze differences in the hardness of the enamel surface by immersing it in extract of cacao rind and fluoride. Materials and Methods: The dental crowns of 27 square-shaped bovine incisors were planted in a round-shaped resin mold and divided into three groups consisting of nine samples. The control group was immersed in artificial saliva, Group I was immersed in artificial saliva with $0.1 \%$ of theobromine cacao rind extract, while Group II was immersed in a combination of artificial saliva and $2 \%$ sodium fluoride (NaF). The measuring of surface hardness was performed using Wolpert Wilson Vickers Microhardness tester after the sample had been immersed in the incubator for 30 min at $37^{\circ} \mathrm{C}$. Results: Those groups immersed in artificial saliva to which $0.1 \%$ theobromine cacao rind extract was added yielded the highest surface hardness. The surface hardness of groups immersed in artificial saliva with the addition of $2 \% \mathrm{NaF}$ was higher than that of the artificial saliva group. Conclusions: There was significant difference in the tooth enamel surface hardness of the groups immersed in cacao rind extract compared with that of the fluoridated groups.
\end{abstract}

Keywords: Cacao rind extract, enamel, fluoride, surface hardness, theobromine

\section{INTRODUCTION}

Enamel is the hardest biological tissue in the human body ${ }^{[1]}$ that even more durable than cartilage and bone. Given its mechanical properties, enamel plays an important role in physiological functions such as biting, chewing, and the protection of underlying structures. Enamel consists of $4 \%$ organic material and $96 \%$ inorganic mineral in the form of hydroxyapatite (HA) ${ }^{[1]}$ Enamel possesses mechanical properties including hardness, elastic properties, and dynamic mechanical properties (viscoelasticity) with hardness being considered the most important mechanical trait of enamel. ${ }^{[1]}$

Various methods have been developed to improve the mechanical properties of enamel in order to prevent the early formation of caries. One of these is the use of fluoride which could be applied in one of two ways: systemic and local. ${ }^{[2]}$ Its provision through topical application can include various

\begin{tabular}{|l|l|}
\hline \multicolumn{2}{|c|}{ Access this article online } \\
\hline Quick Response Code: & Website: \\
\hline & www.jioh.org \\
\hline & \\
\hline
\end{tabular}

forms, one of which is $2 \%$ sodium fluoride $(\mathrm{NaF}) \cdot{ }^{[3]}$ However, topical fluoride applications should be carefully monitored due to the potential for overingestion and toxicity. ${ }^{[2]}$ Fluoride is rapidly absorbed in the gastrointestinal tract, a process to which children are especially susceptible. Moreover, the risk of chronic fluor toxicity manifested as fluorosis or mottled enamel exists if excessive quantities of fluoride are ingested. ${ }^{[2]}$

Research has discovered alternatives to the use of chemicals consisting of basic herbal ingredients. Indonesia is one of

Address for correspondence: Dr. Nirawati Pribadi, Department of Conservative Dentistry, Faculty of Dental Medicine, Universitas Airlangga, Jl. Mayjend Prof. Dr. Moestopo No. 47, Surabaya 60132, Indonesia. E-mail: nirawati-p@fkg.unair.ac.id

This is an open access journal, and articles are distributed under the terms of the Creative Commons Attribution-NonCommercial-ShareAlike 4.0 License, which allows others to remix, tweak, and build upon the work non-commercially, as long as appropriate credit is given and the new creations are licensed under the identical terms.

For reprints contact: reprints@medknow.com

How to cite this article: Pribadi N, Citra A, Rukmo M. The difference in enamel surface hardness after immersion process with cocoa rind extract (Theobroma cacao) and fluoride. J Int Oral Health 2019;11:100-3. 
the largest producers of cacao rind which contains active compounds such as theobromine, a methylxanthine of alkaloids. ${ }^{[4]}$ Theobromine is also present in cacao leaves, although in very small concentrations compared to the rind..$^{[4]}$ Theobromine compounds can increase tooth enamel surface hardness by interstitial reactions between the HA crystals and theobromine on the enamel surface ${ }^{[5,6]}$ Moreover, the presence of Van Der Waals force and a tendency for attraction between atoms might further promote the hardening process and the surface strength of tooth enamel. ${ }^{[7]}$

This study makes use of bovine teeth as samples by reason of their enamel structure having much in common with that of human teeth ${ }^{[8]}$ Furthermore, they are more readily available in large numbers, are in good condition, are more sizeable, and have a flat surface, while being free of carious lesions and other defects. ${ }^{[8]}$ This study also makes use of theobromine cacao rind extract at a concentration of $0.1 \%$ which is a level both effective in increasing tooth enamel surface hardness and safe, in that it does not produce side effects when used or consumed. ${ }^{[9-11]}$

In recent years, the potential use of theobromine in the field of dentistry has become the object of study. The surface hardness of tooth enamel is associated with mineral exchange in the enamel layer. $200 \mathrm{mg} / \mathrm{L}$ of theobromine has a positive effect on increased surface hardness and the remineralization of enamel. A study concluded that the administering of $200 \mathrm{mg} / \mathrm{L}$ of concentrated theobromine for $5 \mathrm{~min}$ might increase its intensity in surface enamel. ${ }^{[12]}$ Another in vitro study showed the effectiveness of theobromine in increasing intensity to tooth enamel surface. ${ }^{[9]}$ This investigation was performed to analyze the difference in tooth enamel surface hardness through immersion in extract of cacao rind compared to fluoride.

\section{Materials and Methods}

This study constituted a laboratory-based experiment incorporating the use of a sample consisting of bovine incisors which were divided into the crown and root. The dental crown

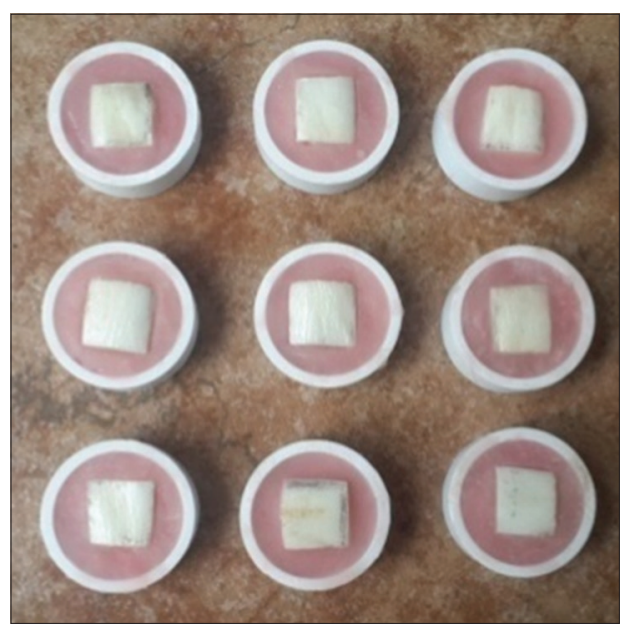

Figure 1: Samples of the study was then cut into a $1 \mathrm{~cm} \times 1 \mathrm{~cm}$ square which was planted in a circular $2 \mathrm{~cm} \times 2 \mathrm{~cm} \times 1.5 \mathrm{~cm}$ resin mold [Figure 1].

A total of 27 mandibular incisors had been prepared. The samples were divided into three groups: a negative control group (artificial saliva) which made from calcium chloride $0.111 \mathrm{~g}$, sodium dihydrogen phosphate $0.156 \mathrm{~g}$, sodium chloride $2.05 \mathrm{~g}$, sodium acetate $2.05 \mathrm{~g}, \mathrm{NaCl} 6.7 \mathrm{~g}, \mathrm{NaHCO}_{3} 1.5 \mathrm{~g}$, $\mathrm{KCl} 1.2 \mathrm{~g}, \mathrm{Na}_{2}(\mathrm{PO})_{4} 0.2 \mathrm{~g}$, and KSCN $0.33 \mathrm{~g}$ in Laboratory of Organic Chemistry, Faculty of Science and Technology, Universitas Airlangga, Surabaya, Indonesia that was considered to be an in vitro medium and had no effect on tooth enamel surface hardness; Group I - artificial saliva to which was added $70 \%$ ethanol extract of $0.1 \%$ cacao rind (Theobroma cacao) obtained from East Java Industry Research and Consulting Agency and Group II - artificial saliva to which was added 2\% NaF supplied by the Organic Chemistry Laboratory, Faculty of Science and Technology, Universitas Airlangga. The groups were immersed in an incubator for $30 \mathrm{~min}$ at $37^{\circ} \mathrm{C}$. Thereafter, measurement of surface hardness was conducted using a Wolpert Wilson Vickers Hardness Tester VH3100 (Buehler, Tokyo, Japan). Measurements were taken at two different points with a $200-\mathrm{g}$ load. The value of surface hardness was obtained in the form of Vickers hardness number units.

The data obtained were analyzed by one-way ANOVA for significance and a post hoc multiple comparison test by a Tukey honestly significant difference method using SPSS Statistic Version 25 (IBM Corp, New York, USA) to discover the differences in the hardness values of tooth enamel surface between the study groups.

\section{RESULTS}

Data were obtained regarding the hardness value of the tooth enamel surface at each indentation, with the average value and standard deviation of each group being subsequently calculated [Figure 2].

The highest concentration of surface tooth enamel, $271.2 \mathrm{~kg} / \mathrm{mm}^{2}$, was found in Group I whose mean surface tooth

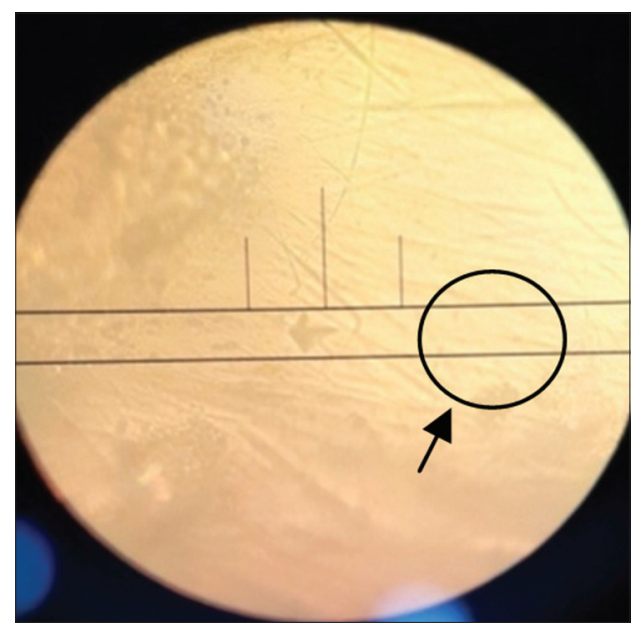

Figure 2: Result of indentation 
Pribadi, et al.: Enamel surface hardness after immersion with theobromine

\begin{tabular}{|c|c|c|c|}
\hline Group & The amount of samples & Means $\left(\mathrm{kg} / \mathrm{mm}^{2}\right)$ & SD \\
\hline Control & 9 & 219.6 & 2.06 \\
\hline I & 9 & 271.29 & 7.87 \\
\hline II & 9 & 256.08 & 5.53 \\
\hline
\end{tabular}

Table 2: Difference test results with post hoc multiple comparison test

\begin{tabular}{lccc}
\hline & Control & I & II \\
\hline Control & & $0.000^{*}$ & $0.000^{*}$ \\
I & $0.000^{*}$ & & $0.000^{*}$ \\
II & $0.000^{*}$ & $0.000^{*}$ & \\
\hline
\end{tabular}

*Significance differences

enamel value was $256 \mathrm{~kg} / \mathrm{mm}^{2}$. In the control group, the lowest mean surface tooth enamel value was $219.6 \mathrm{~kg} / \mathrm{mm}^{2}$ [Table 1].

Normality and homogeneity tests were conducted on the results of this study. The normality test (Kolmogorov-Smirnov test) confirmed the data of all groups as having $P>\alpha(\alpha=0.05)$ and therefore being normally distributed. The homogeneity test consisted of a Levene's test. Based on the analysis conducted, $P=0.051$ and therefore, $P>\alpha(\alpha=0.05)$, confirming that the variance of data between groups was homogeneous.

A one-Way ANOVA test result indicated a significant influence of $P<\alpha(\alpha=0.05)$. The value of the significance test result was $P=0.000$ indicating that $P<\alpha(\alpha=0.05)$. Hence, there was a significant difference in enamel surface hardness across all three groups. The result of the post hoc multiple comparison test confirmed that there is a significant difference in the enamel surface hardness between the control group and Group I, between the control group and Group II, and also between Group I and II [Table 2].

\section{DISCUSSION}

Tooth enamel is made up of $96 \%$ inorganic material consisting of $\mathrm{Ca}_{10}\left(\mathrm{PO}_{4}\right)_{6}(\mathrm{OH})_{2} \mathrm{HA}$ crystals, where the $\mathrm{OH}^{-}$of the crystals are highly reactive to ion exchanges. The apatite crystals also contain microtunnels that allow other ions and molecules to pass through them. ${ }^{[13]}$ Changes to the apatite crystal structure present in the surface of the enamel can cause shifts in the mechanical properties of the crystal, one of which is a change in tooth enamel surface hardness.

The use of artificial saliva as a negative control group was based on data analysis of the results of previous trial studies, which compared the enamel of teeth that had been immersed in artificial saliva with that of untreated teeth. Data analysis of the trial study results reveals no significant difference. It could be concluded, therefore, that artificial saliva apparently produces no effect on tooth enamel surface hardness.
The hardest tooth enamel surface was recorded by Group I with an average value of $271.2 \mathrm{~kg} / \mathrm{mm}^{2}$. This occurred due to an interstitial reaction between theobromine and the HA crystals present in the enamel surface of the tooth. The inherent insertion of theobromine in the microtunnel that was found in the HA crystal structure could cause an interstitial defect which occurs when there is an extra atom or ion that infiltrates the crystal structure in a normally uninhabitable position. ${ }^{[5,14]}$ The interstitial defect that occurs can produce internal stress within the crystal structure. Crystals that do not initially experience internal stress could easily shift when there is external stress that exceeds the threshold of tolerance. However, when internal stress exists within the crystal structure, it requires greater external stress to make the crystal shift. Consequently, it could be argued that resistance to the occurrence of a shift increases. ${ }^{[5,6,13]}$ Due to the presence of such resistance, the crystal requires greater pressure to render it deformed. The amount of effort required to deform a crystal is called the degree of deformation. The higher the degree of deformation of a crystal, the greater its strength and hardness. ${ }^{[5,6,13]}$

Another factor that could produce the high value of tooth enamel surface hardness in Group I is that of Van Der Waals forces which occur because calcium atoms in HA crystals belong to the metal Group II A. These atoms tend to turn into cations, $\mathrm{Ca}^{2+}$, which lack electrons, with the result that $\mathrm{Ca}$ could be called the positive partial $(\delta+)$. In contrast, $N$ in theobromine belongs to Class $\mathrm{V}$ A which possesses an excess of electrons. $\mathrm{N}$ could, therefore, be termed a negative partial $\left(\delta^{-}\right)$. Van Der Waals force could emerge between the positive and negative partial due to the tendency for mutual attraction between atoms to occur. ${ }^{[7]}$ With the pull forces between the atoms, it becomes more difficult for the bond to be released. It requires energy for a spontaneous break in a particular bond to be effected, with the prerequisite amount being referred to as bonding energy. The increased energy of bonding could cause the crystal structure to become more compact and it requires more energy to release the bond. ${ }^{[15]}$ In this study, Group II demonstrated an average tooth enamel surface hardness value of $256.08 \mathrm{~kg} / \mathrm{mm}^{2}$, which is higher than that of the control group with an average value of $219.6 \mathrm{~kg} / \mathrm{mm}^{2}$.

The tooth enamel surface hardness in Group II seems to be higher than the control group due to the presence of $\mathrm{OH}^{-}$in apatite crystals which is highly tolerant of substitution. In Group II, substitution reactions would occur which convert the $\mathrm{Ca}_{10}\left(\mathrm{PO}_{4}\right)_{6}(\mathrm{OH})_{2} \mathrm{HA}$ crystals into fluorapatite $\mathrm{Ca}_{10}\left(\mathrm{PO}_{4}\right)_{6} \mathrm{~F}_{2} \cdot{ }^{[16]}$ During the formation of the fluorapatite crystalline, anion substitution occurred between $\mathrm{OH}^{-}$and $\mathrm{F}^{-}$ions. The strong electronegative property of $\mathrm{F}^{-}$leads to increased energy bonding between the crystallizing elements of the fluorapatite. The higher the bonding energy, the more difficult it would be to release since it takes more energy to do so.

The presence of stronger bonding energy leads the arrangement of the fluorapatite crystals to be more compact and difficult 
to break apart than that of the HA crystals. ${ }^{[6]}$ The increase in the bonding energy could cause a transformation of the mechanical properties, namely an increase in tooth enamel surface hardness. ${ }^{[14]}$ However, this increase in hardness is not as great as that in Group I. This study shows that the surface hardness of enamel after an immersion process involving theobromine cacao rind extract appears to be higher compared to the one using fluoride.

\section{Conclusions}

Enamel surface hardness after immersing process with theobromin cocoa rind extract appears to be higher compared to the immersing process with fluoride.

\section{Financial support and sponsorship}

Nil.

\section{Conflicts of interest}

There are no conflicts of interest.

\section{References}

1. Zhang YR, Du W, Zhou XD, Yu HY. Review of research on the mechanical properties of the human tooth. Int J Oral Sci 2014;6:61-9.

2. Sirat NM. Pengaruh aplikasi topikal dengan larutan NaF dan SnF2 dalam pencegahan Karies Gigi. J Keperawatan Gigi Poltekkes Denpasar 2014;2:222-32.

3. Rajendran A, Sivapathasundharam B. Shafer's Textbook of Oral Pathology. $7^{\text {th }}$ ed. New Delhi: Elsevier; 2012.

4. Franco R, Oñatibia-Astibia A, Martínez-Pinilla E. Health benefits of methylxanthines in cacao and chocolate. Nutrients 2013;5:4159-73.
5. Callister WD, Rethwisch DG. Materials Science and Engineering an Introduction. $9^{\text {th }}$ ed. New York: John Wiley \& Sons; 2014.

6. Suherman W. Metal Science. $1^{\text {st }}$ ed. Surabaya: Department of Mechanical Engineering, Faculty of Industrial Technology, Institut Teknologi Sepuluh Nopember; 2003. p. 14-23.

7. Fessenden RJ, Fessenden JS. Organic Chemistry. $3^{\text {rd }}$ ed. Jakarta: Erlangga; 1997.

8. Yassen GH, Platt JA, Hara AT. Bovine teeth as substitute for human teeth in dental research: A review of literature. J Oral Sci 2011;53:273-82.

9. Syafira G, Permatasari R, Wardani N. Theobromine effect on enamel surface microhardness : In vitro. J Dent Indones 2012;19:32-6.

10. van den Bogaard B, Draijer R, Westerhof BE, van den Meiracker AH, van Montfrans GA, van den Born BJ, et al. Effects on peripheral and central blood pressure of cocoa with natural or high-dose theobromine: A randomized, double-blind crossover trial. Hypertension 2010;56:839-46.

11. Septriyani K, Utomo RB, Titien I. The Effect of Concentration and Duration of Immersion in Cocoa Seed Extract Solution (Theobroma cacao 1.) to Surface Hardness and Crystal of Apatite Enamel (in vitro study). Thesis. Universitas Gadjah Mada: Yogyakarta; 2015. p. 49.

12. Kargul B, Özcan M, Peker S, Nakamoto T, Simmons WB, Falster AU, et al. Evaluation of human enamel surfaces treated with theobromine: A pilot study. Oral Health Prev Dent 2012;10:275-82.

13. Nasution AI, Zawil C. The comparison of enamel hardness between fluoride and Theobromine application. Int J Contemp Dent Med Rev 2014:1-4.

14. Gunawan, Harun A. Effect of apatite crystal changes, retention rate and flour intrusion on enamel solubility after treatment of anchovy (s. Insularis) solution. J Phys Conf Series 2006;884:7-8.

15. Chang R. Basic Chemistry, Core Concepts. $3^{\text {rd }}$ ed., Vol. 1. Jakarta: Erlangga; 2005.

16. Hiremath S. Textbook of Preventive and Community Dentistry. $2^{\text {nd }}$ ed. New Delhi: Elsevier; 2011. 